\title{
Challenges of digitalization and artificial intelligence for modern economies, societies and management
}

\author{
Rolf Clauberg \\ Peoples' Friendship University of Russia (RUDN University) \\ 6 Miklukho-Maklaya St, Moscow, 117198, Russian Federation
}

\begin{abstract}
This study aims at identifying the challenges of digitalization and artificial intelligence for modern economies, societies and business administration. The implementation of digitalization schemes as Industry 4.0 are presently official policy of many developed countries. The goal is optimization of production processes and supply chains. Artificial intelligence is also affecting many fields. Both technologies are expected to substantially change working conditions for many people. It is important to identify the kind and impact of these changes and possible means to minimize negative effects. For this purpose, this study uses previous results about the disappearance of manufacturing jobs in the USA and their impact on different groups of society together with technical information about the new technologies to deduce expected changes caused by digitalization and artificial intelligence. Results are that both technologies will destroy large numbers of jobs and complete job classes while at the same time creating new jobs very different from the ones destroyed. Extensive permanent education and re-education of employees will be necessary to minimize negative effects, probably even changes to a more broad-based education to improve the potential of job changes into completely new fields. In addition, the technical information about digitalization in cyber-physical systems points to dangers that will require solutions on the international level.
\end{abstract}

Keywords: artificial intelligence, cyber-security, cyber-terrorism, digitalization, gross domestic product, Industry 4.0

\section{Introduction}

Technological evolution is visible in every part of the human history at least from the Stone Age towards today. Mostly it substantially improved human living conditions. But sometimes it happened as an industrial revolution. Most authors distinguish four such revolutions: the mechanical loom and the steam engine, electricity and the assembly line, the computer, and today's plans for digitalization and Industry 4.0 based on cyber-physical systems. Each technology revolution creates challenges on the company as well as the regional and national level. Already the first industrial revolution led to upheavals by weavers doing their job in a self-employed mode from home, when the first industrial companies using large numbers of mechanical looms and later even power looms destroyed their source of income. A second important impact on societies always was globaliza-

(C) Clauberg R., 2020

(i) This work is licensed under a Creative Commons Attribution 4.0 International License https://creativecommons.org/licenses/by/4.0/ 
tion. Adam Smith's work "An Inquiry into the Nature and Causes of the Wealth of Nations" published in 1776 (Smith, 1776) argues that global trade is best for all nations by allowing each nation to focus on creating those products which it can produce best and import the other products cheaper from other countries. However, just like technical revolutions, global trade can cause severe disruptions for specific groups of people, if for example developing nations catch up with developed nations and then can produce those products cheaper that were previously produced in developed countries. Industrial revolutions as well as global trade changes can show good growth in gross domestic product (GDP) per head while at the same time creating substantial loss in net-worth for large groups of people in the same country.

\section{Literature review}

The most important foundation of this article is the study of publications and information on accessible web pages describing the technical background of digitalization techniques as Industry 4.0 by the German Ministry of Education and Research ${ }^{1}$, the Commission of the European Union², and scientific articles (Cachin et al., 2019; Wu et al., 2016; Kawaguchi, 2019). Supply and value chains are described in (Fingar, Aronica, 2001). In addition, the role of artificial intelligence (AI) is considered since it plays a major role in practically all digitalization techniques. A second foundation is the study of the impact of the disappearance of complete job classes through globalization and automatization (Clauberg, 2019) in the United States of America on the economic situation of different groups of society based on data from the US Federal Reserve Bank, the US Department of Labor, and the World Bank.

\section{Methods}

From the literature about the new digital technologies, we deduct the expected impact on related jobs, i.e. the kind of jobs which will see substantial changes but will show no serious decrease in numbers, the kind of jobs which must be expected to decrease substantially due to automatization, and the kind of jobs which will be newly created due to the new technologies. From the analogy between the changes in technology and the shift of jobs from developed to developing countries, we deduct that the disappearance of job classes due to technology evolution will cause very similar effects on corresponding society groups as the disappearance caused by shifting jobs to different countries. In addition, we deduct that such effects can also be caused by badly trained artificial intelligence systems.

\section{Results}

The following sections will first briefly describe the specific impact of the loss of manufacturing jobs in the United States of America (USA) (Clauberg, 2019) as an example of a challenge on national and even international level. Then we will focus on the specific features and economic impact of Industry 4.0 and artificial intelligence (Russell, Norvig, 2009; Nayak, Dutta, 2017) respectively.

${ }^{1}$ Federal Ministry for Education and Research of Germany. (2018). Digital economy and society. Retrieved October 4, 2018, from https://www.bmbf.de/de/zukunftsprojekt-industrie-4-0848.html (In German.)

${ }^{2}$ EU Commission. (2018). Digital Single Market. Retrieved October 4, 2018, from https:// ec.europa.eu/digital-single-market/en 
USA Manufacturing. The dynamics of the world economy (Figure 1) (Hanson, 2000 ) in the long term, starting from about the $8^{\text {th }}$ millennium BC, clearly shows what people have achieved with the invention of machines and replacing themselves with them in the production of material goods. According to economist Robin Hanson, the doubling time of the economy (hunting and collective) of the primitive Pleistocene society was 224 thousand years, the agricultural society - 909 years, the industrial society -6.3 years. It is the development of machines, that at one time led to the emergence of industry, followed by an increase in production volumes, welfare, radically improving living conditions of people and, accordingly, the growth of the population of the Earth. Since the time of the first industrial revolution, the gross domestic product showed 155-fold growth, and the population 9-fold. However, that growth was far from linear. It acquired an exponential form at the beginning of the last century. It was then that enterprises began to represent rather complex organizations of people, cooperated in a single production process, and the scientific organization of production and management appeared at these enterprises. Figure 2 created with data from pages 241 (population) and 261 (World Gross Product) of (Maddison, 2006) shows this evolution. World Gross Product is given in 1990 international dollars.

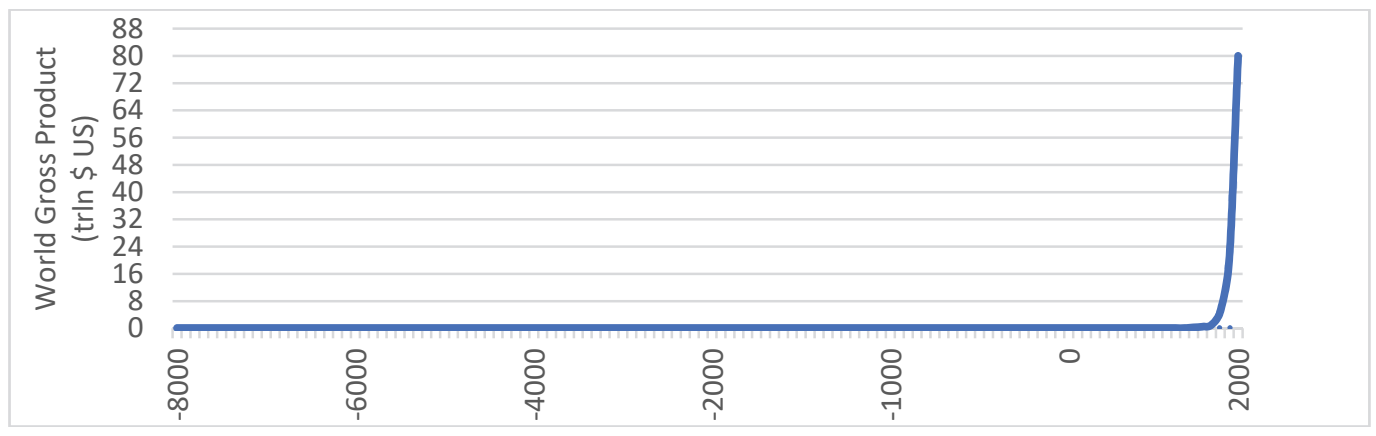

Figure 1. World population from 10000 years ago until now Source: (Hanson, 2000).

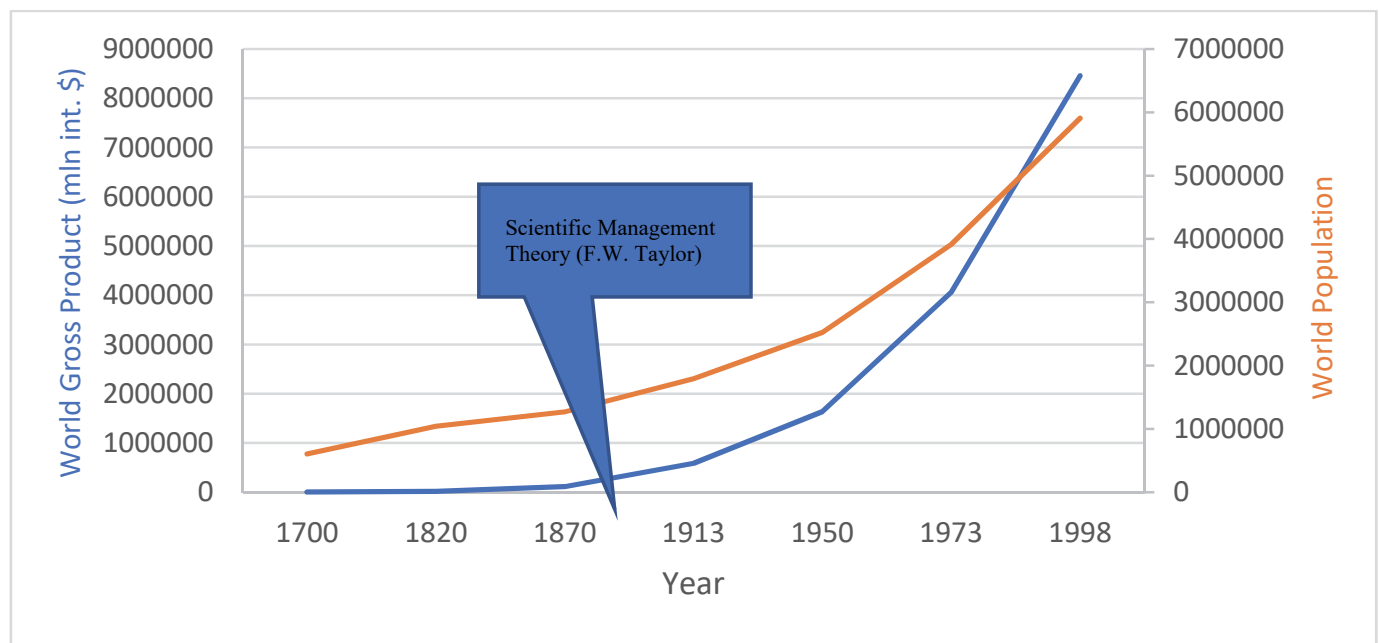

Figure 2. Evolution of world population and world gross product 
Today, computers have already taken over the implementation of a significant part of not only manufacturing routines, but managerial routine tasks as well and continue to further free managers from them. Forrester Research ${ }^{3}$, an American company specializing in various market research, conducted an analysis in 2015 and made a forecast of what percentage of functions or tasks solved by a person in various professional fields of activity will be automated. Its forecast is presented in Table. It is clearly visible that Forrester Research predicts the largest automatization in the field of management, business, and finance where it is expected to even reach $92 \%$ in 2022 .

Table

Forrester Research 2015: Prediction of degree of automatization for specific professional fields

\begin{tabular}{|c|c|c|c|c|c|c|c|c|}
\hline $\begin{array}{l}\text { Professional } \\
\text { field }\end{array}$ & 2015 & 2016 & 2017 & 2018 & 2019 & 2020 & 2021 & 2022 \\
\hline $\begin{array}{l}\text { Management, } \\
\text { business, } \\
\text { finance }\end{array}$ & $9 \%$ & $19 \%$ & $29 \%$ & $40 \%$ & $51 \%$ & $64 \%$ & $77 \%$ & $92 \%$ \\
\hline $\begin{array}{l}\text { Security } \\
\text { services }\end{array}$ & $6 \%$ & $12 \%$ & $19 \%$ & $26 \%$ & $35 \%$ & $44 \%$ & $54 \%$ & $66 \%$ \\
\hline Trade & $7 \%$ & $14 \%$ & $23 \%$ & $32 \%$ & $41 \%$ & $52 \%$ & $63 \%$ & $76 \%$ \\
\hline $\begin{array}{l}\text { Office and } \\
\text { administrative } \\
\text { functions }\end{array}$ & $7 \%$ & $15 \%$ & $23 \%$ & $32 \%$ & $42 \%$ & $52 \%$ & $64 \%$ & $76 \%$ \\
\hline $\begin{array}{l}\text { Agriculture, } \\
\text { fishing, } \\
\text { forestry }\end{array}$ & $6 \%$ & $11 \%$ & $18 \%$ & $24 \%$ & $32 \%$ & $40 \%$ & $50 \%$ & $62 \%$ \\
\hline $\begin{array}{l}\text { Construction } \\
\text { and mining }\end{array}$ & $6 \%$ & $11 \%$ & $18 \%$ & $24 \%$ & $31 \%$ & $40 \%$ & $49 \%$ & $60 \%$ \\
\hline $\begin{array}{l}\text { Equipment } \\
\text { installation, } \\
\text { maintenance } \\
\text { and repair }\end{array}$ & $6 \%$ & $11 \%$ & $17 \%$ & $24 \%$ & $31 \%$ & $39 \%$ & $49 \%$ & $60 \%$ \\
\hline Manufacturing & $6 \%$ & $11 \%$ & $18 \%$ & $24 \%$ & $32 \%$ & $40 \%$ & $50 \%$ & $61 \%$ \\
\hline Transportation & $6 \%$ & $11 \%$ & $18 \%$ & $25 \%$ & $32 \%$ & $41 \%$ & $51 \%$ & $62 \%$ \\
\hline
\end{tabular}

Source: Forrester Research. (2015). Prediction of degree of automatization for specific professional fields. Retrieved April 7, 2020, from https://go.forrester.com/research/

A recent article (Clauberg, 2019) analyzed the impact of the loss in manufacturing jobs in the USA, showing that according to the US Department of Labor between 1998 and 2010 about $35 \%$ of jobs were lost in manufacturing and according to data from the World Bank the leading position of the USA generating $27 \%$ of world manufacturing value-add decreased to $17 \%$ while that of China increased from 7 to $24 \%$ effectively taking over the position as leading manufacturing nation. While this looks like a clear moving of manufacturing from the USA to China, a view on the manufacturing value-add in US dollars, shows that the manufacturing value-add of the USA in constant US dollars still increased despite the loss of 35\%

\footnotetext{
${ }^{3}$ Forrester Research. Retrieved April 7, 2020, from https://go.forrester.com/research/
} 
of jobs. Hence, manufacturing productivity of those parts still in the US must have increased and the only possible explanation seems to be enhanced automatization. An important point is that GDP per head for the USA grew nicely from 1960 towards today. Only the worldwide financial crisis of 2008 caused the values for 2009 and 2010 to be smaller than the value for 2008, but 2011 is again already larger than 2008. So, we have a loss of 35\% of manufacturing jobs from 1998 to 2010 accompanied by good growth in GDP per head for the US.

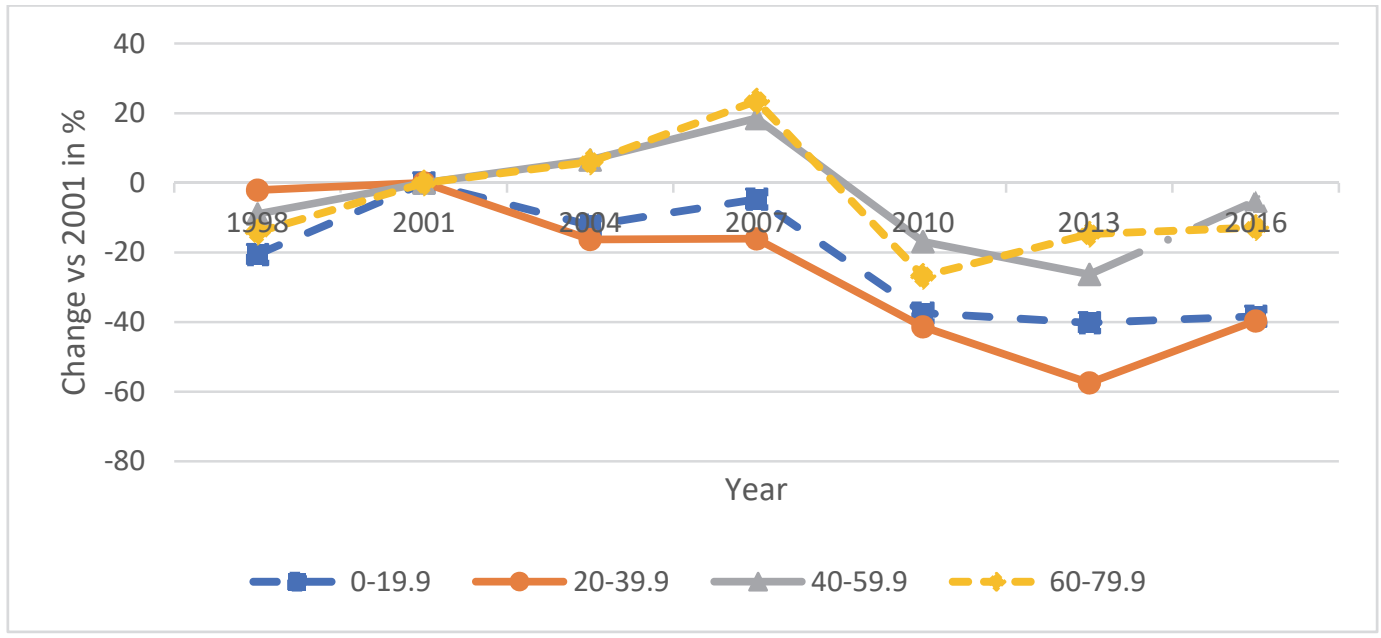

Figure 3. USA net-worth (median values) changes vs 2001 for different income groups

Source: US Federal Reserve Bank. (2017). Consumer survey of the Federal Reserve Bank. Table 4. Retrieved October 4, 2018, from https://www.federalreserve.gov/econres/files/scf2016_tables_public_real_ historical.xlsx

As a next step we will look at the economic impact on different parts of the society. Figure 3 in (Clauberg, 2019) based on the data in Table 4 of the US Federal Reserve Bank's consumer survey ${ }^{4}$ shows that the median values for networth decreased by about $40 \%$ for the two lowest income groups $(0-19.9 \%$ and $20-39.9 \%$ ) from 2001 to 2016 . The net-worth changes for the next two groups (40-59.9\% and $60-79.9 \%$ ) are still negative with -5 and $-13 \%$ respectively. Only the people in the highest $20 \%$ of income group saw net-worth improvement with the top $10 \%$ earners gaining $45 \%$. A closer look at the data reveals that the loss for the working-class group (20-39.9\% group) started about 2001. In the years from 1989 to 2001, the values were nearly constant (Figure 4 of (Clauberg, 2019)). In Figure 3 we show the data of Figure 4 of (Clauberg, 2019) again, but now as change in net-worth with respect to the year 2001 and only from 1998 to 2016. Also, we leave off the two highest income groups for better visibility of the changes for the lower income groups. Here we have to say that the survey by the US Federal Reserve Bank is done only every three years. Thus, there are values for 1998, 2001 , and so on, but not for the years between. The income group in the 20 to $39.9 \%$ group is usually called the working-class group in the USA.

${ }^{4}$ US Federal Reserve Bank. (2017). Consumer survey of the Federal Reserve Bank. Retrieved October 4, 2018, from https://www.federalreserve.gov/econres/files/scf2016_tables_public_real_historical.xlsx 
Hence, we can conclude, that the loss of manufacturing jobs was the main cause for the strong decrease in net-worth values for the US working class. In contrast, the 40-59.9 and 60-79.9\% income groups show no decrease in net-worth from 2001 to 2007 . These groups were practically not affected by the decrease in manufacturing jobs, but were hit by the financial crisis from 2008 as visible in their drops in net-worth from 2007 to 2010 . Therefore, the data show that job specific effects can severely affect specific social groups while having no visible effect on others or even show good growth in GDP per head for the country in total.

In 2016 the USA elected a president without experience in politics but the image of a great businessman. He won the election with the promise of bringing back the jobs from China. Consequently, US politics changed from supporting global trade to a protectionist position and fighting of economic wars. Therefore, the negative impact on specific groups in the USA had consequences even on the international level.

Industry 4.0. Already before the year 2000 there was a substantial boom in so-called e-business which ended in the well-known dot-com crash of 2000. After this, the real digital economy started. Books described e-commerce, e-procurement, electronic marketplaces, digital value chains, digital marketplaces, e-services, business models and technologies for the digital business (Fingar, Aronica, 2001). The digitalization of all business processes became the overwhelming theme of the $21^{\text {st }}$ century. It is also the official policy of the European Union and many countries. Germany introduced a government-sponsored program called "Industry 4.0". In the USA several consortiums started research and development collaborations known under the name of "Smart factories" (Wu et al., 2016). Both programs aim at connecting operational technology (OT), the Industrial Internet of Things (IIoT) (Wu et al., 2016; Jeschke et al., 2017) with information technology (IT) and the internet as cyber-physical systems, thereby integrating entire value chains. In addition, they aim for highly flexible computer-controlled production tools like $3 \mathrm{D}$ printing or additive manufacturing with various materials ${ }^{5}$. Here, one goal is a substantial increase in manufacturing flexibility that will allow switching to a different model of a product or even a different product by just switching to another input data set for the next production run. This would change economies of scale in a way that allows the generation of highly personalized products at costs now only possible for a larger number of equal products. In other words, single-lot production shall become economically as viable as the production of large numbers of lots.

Operational technology with cyber-physical systems uses a huge number of sensors to automatically determine the status of production processes as well as actuators to adapt the processes as needed. This also includes to order new materials for the production or to replace parts, which show signs of degradation. Blockchain a new technology to perform transactions in a secure, provable way, can use so-called "smart contracts" (Watanabe et al., 2016; Wu et al., 2016) to allow the computer system to order all these materials and components automatically without human involvement after the first setup of the contracts in electronically executable code. Hence, the production system will automatically determine the ma-

${ }^{5}$ The Economist. (2013, September 5). 3D printing scales up. Retrieved October 4, 2018, from https://www.economist.com/technology-quarterly/2013/09/05/3d-printing-scales-up 
terials it needs to generate the new product from the input data set, then what is available and what is missing, and finally automatically order every missing component with the use of smart contracts.

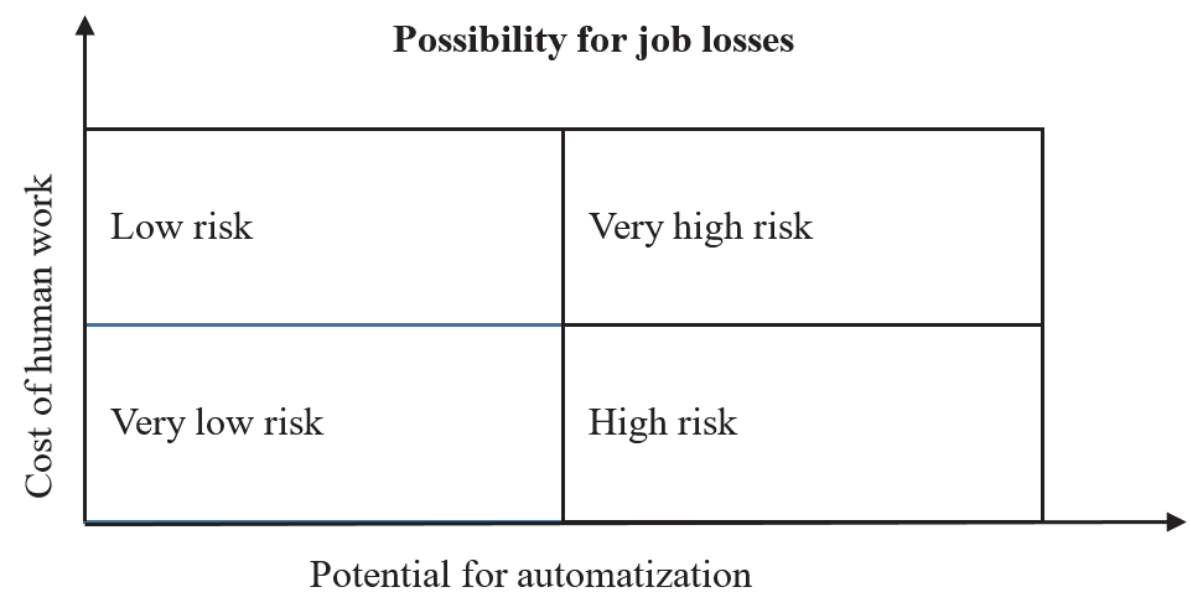

Figure 4. Job risk for Industry 4.0

Source: author's own elaboration.

Therefore, the new factories will not only reduce the number of direct production employees in a plant, but even impact other areas like procurement or bookkeeping.

Figure 4 shows the possibility for job losses in Industry 4.0 assuming that no artificial intelligence is involved. The risk for job losses is deduced from the observations made for the manufacturing losses in the USA. Jobs were mainly shifted to China, because the cost of human work there was much lower. But the parts of the industry staying in the USA showed a clear increase in productivity, which we assign to increased automatization. The relevant factor here is the cost of automatization versus the cost of human work. Of course, the potential for automatization of the job determines the main risk. The higher the potential for automatization within a job, the larger the risk that this will happen. However, our deduction that the risk of job losses due to automatization is higher for jobs where the cost of human work is high is the other important variable. Therefore, we see the largest risk for automatization in jobs with a high potential for automatization and high cost for human work. This of course also means that the thread of automatization is a force that keeps salaries and inflation down in a similar way as the thread of globalization.

Industry 4.0 will also create new jobs. These jobs will mainly be in all parts, which enable fully automatic computer control of production - highly flexible production machines (Wu et al., 2016) with computer control enabled by specific software. Manual operation of machines will be needed only in case of maintenance activities and will be provided as a service by the companies that build the machines. Hence, the new jobs will be mainly in the design of special machines and corresponding control software.

Another aspect to consider here is cyber-security. The coupling of cyber-physical systems to the internet for more efficient business control down to the operational 
technology (OT) level generates unprecedented security risks, affecting security of humans as well as the economies of countries. Previously, OT systems were completely separated from the internet and computer viruses could penetrate OT systems only when an infected device like an USB-stick was connected to a physical system for software changes or updates. Now it is accessible to cyberattacks through the internet as every other computer system. The important point with cyber-physical systems is that these systems control critical infrastructure as well as industrial plants producing poisonous or explosive chemicals (Clauberg, 2019).

Artificial intelligence. Another technology which will substantially impact existing jobs even far beyond manufacturing is artificial intelligence. At the moment AI (Russell, Norvig, 2009; Nayak, Dutta, 2017) is still in its infancy. There are mainly two types of systems in use - algorithmic based systems and neural networks. The algorithmic approach is mainly used to analyze text libraries for specific information or to classify input data according to specific rules. Algorithmic solutions may be quite complex using multiple algorithms for analyzing the same data and classify these data based on the combined results of all used algorithms (Varga et al., 2017). Neural-network based solutions are limited mainly to all kind of pattern recognition. Here, the use of several types of neural networks, sometimes a combination of neural networks, has let to huge progress in the recognition and classification of image, voice, and behavioral patterns. AI based image analyzes are already frequently used in the medical area for detecting specific anomalies in x-ray or magnetic-resonance tomographic pictures. In addition, there is great progress in robotic systems, which make those systems safe enough to operate moving robots in close vicinity to humans.

However, despite all these progress in some limited areas, we are still far away from general artificial intelligence. Nevertheless, the present systems already affect existing jobs. In contrast to previous technologies, AI also affects jobs of highly educated people through its role as an expert support system. In general, enhancing human productivity means more products or services with the same number of human resources or the same number of products or services with less human resources. AI has the potential to substantially increase productivity in many different areas. Back-end jobs are the first candidates for job reductions. For jobs where the productivity improvement due to the use of AI tools does not allow a reduction in the number of employees, the productivity growth will result in quality improvements. Corresponding jobs are e.g. in the medical area where the possibility to analyze huge data sets to find better treatments will not allow to reduce the number of doctors or nurses. For back-office jobs, like analyzing insurance claims for validity and correctness, the AI tools will allow to handle the same number of claims with much fewer people. Front-end jobs are usually only endangered if the customer himself accepts more activities from his own side. One example for this is the strong reduction in bank counters due to online banking and use of automatic teller machines. Another aspect with present AI solutions is that they are best in doing functions that are repeated over and over again. The reason is that neural networks need large training times to learn their job. Every change in the job requires new training. Also, algorithmic based AI solutions must be adapted for every change or must be designed as hugely complex systems to achieve a minimum degree of flexibility. Figure 5 shows the corresponding figure to Figure 4. 


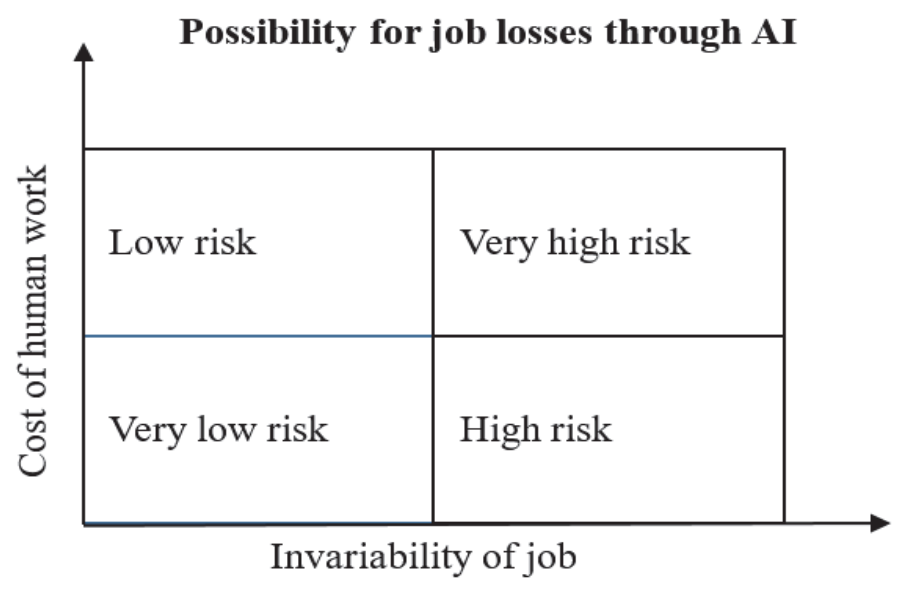

Figure 5. Job risk for artificial intelligence

Source: author's own elaboration.

The role of cost of human work is the same as in Figure 4. In contrast to Figure 4 , potential for automatization is replaced by invariability or immutability of job to account for the necessary training or adaptation of AI systems to any relevant changes in the corresponding job function. If we consider that highly educated people may be replaced by AI systems and higher education is often considered equal to higher salaries, than Figure 5 includes the possibility that the job of a less educated, cheaper human resource may be saver against replacement by AI systems than that of a higher educated person. A conclusion, which contradicts the claims by many education organizations. Another aspect relevant for Figure 5 is the probability that the cost of new AI systems may decrease over time, finally replacing jobs where human work was too cheap to be replaced in the first stages of AI development.

Anyhow, in all areas where the new tools offer improvements there will be substantial changes to the existing jobs in these areas. Being capable to use the new tools will be a necessity for those working in these fields. Considering the speed of changes in the new technologies this will require constant learning, reeducation, and training for many employees. Considering new jobs created by AI they will be mainly in the development of specific hardware to enable AI - hardware based neural networks, graphical processing units (GPU), and in corresponding software to train the neural networks. These are jobs very different from the jobs, which will be destroyed by AI.

There are three other technical issues with the use of AI, especially neural networks - bias in the learning process, so-called adversarial pictures, and the missing explanation for a decision by the neural network, which might generate strong opposition against the use of AI if not addressed correctly. While huge early blunders like not recognizing a dark-skinned person as human created a lot of uproar, there still are many potential traps with using neural networks for classification of objects. One special case are natural adversarial pictures (Hendrycks et al., 2019). These images can easily be recognized by humans but are mostly misinterpreted by today's AI systems. Many natural adversarial examples are incorrectly classified with high confidence, despite having no adversarial modifications, as they are examples that natural- 
ly occur in the physical world. These examples simply demonstrate that today's AI image classifiers see the world different than humans do. With algorithmic-based AI systems one can analyze the algorithms used and can reconstruct the final classification made by the system. But neural network results completely depend on the data with which the network was trained. One can only analyze the data used for training, not the learning process itself. If badly trained neural network systems are used to measure the performance of employees or the judgement of job-applicants this can generate serious backlashes against corresponding companies as well as the use of AI in general. Especially, if the systems show bias against specific social groups, this can generate the same economic damages for these groups as the disappearance of job classes described in the section about USA Manufacturing above. Companies which don't invest into careful supervision of the training of their AI systems can expect discrimination law suites as well as consumer boycotts.

\section{Conclusion}

In this article, several challenges in digitalization with the new technologies of Industry 4.0 and artificial intelligence were discussed. Both technologies will destroy specific jobs while at the same time generating new, but different jobs. The difference to previous technical revolutions is that Industry 4.0 will go beyond manufacturing since it also affects procurement and bookkeeping. Artificial intelligence will have an even larger impact by even affecting jobs of highly educated people. The example presented about the strong loss in net-worth of nearly $60 \%$ for the US working class during the shift of manufacturing jobs from the USA to China shows the disastrous effects such job losses can have even if GDP per head is nicely growing at the same time. Similar effects must be expected for the impact of Industry 4.0 and AI.

Of course, the new technologies used here, will also create new jobs and it is very well possible that the number of newly created jobs will exceed the number of jobs lost. However, the new jobs will differ substantially from those lost and massive re-education programs may be necessary to limit the impact. Company management, especially human resource management and strategy, as well as the society as a whole will need to adapt to the changes caused by the new technologies. In addition, it must be expected that AI will penetrate new job areas over time, thereby eliminating entire job classes while generating new jobs in different areas. This may even lead to a need for a broader base education to enable faster job changes in the future.

Other challenges are the need to create much safer cyber-physical systems than is possible today, to avoid strongly damaging cyber-attacks on critical infrastructure and industrial plants as well as to invest in strong supervision of AI systems to ensure that they don't discriminate against specific social groups.

\section{References}

Cachin, C., Kind, A., Viswanathan, R., Dasgupta, D., Govindaswamy, S., \& al. (2019, March-May). Blockchain: From Technology to Solutions. Special issue on Blockchain Technology. IBM Journal of Research and Development, 63(2/3). doi: 10.1147/ JRD.2019.2912084. 
Clauberg, R. (2019). Globalization and Technology Evolution: Impact on Economy and Society of the USA. The Herald of the Diplomatic Academy of the MFA of Russia. Russia and the World, (2), 26-40.

Clauberg, R. (2019). International Aspects of Cybersecurity. The Herald of the Diplomatic Academy of the MFA of Russia. Russia and the World, 4(22), 24-38.

Fingar, P., \& Aronica, R. (2001). The Death of "e" and the Birth of the Real New Economy. Tampa, Florida, USA: Megan-Kiffer Press.

Hanson, R. (2000, December). Long-Term Growth as a Sequence of Exponential Modes. Retrieved April 7, 2020, from http://hanson.gmu.edu/longgrow.pdf

Hendrycks, D., Zhao, K., Basart, S., Steinhardt, J., \& Song, D. (2019, July 18). Natural Adversarial Examples. Retrieved October 21, 2019, from https://arxiv.org/pdf/1907.07174.pdf

Jeschke, S., Brecher, C., Song, H., \& Rawat, D.B. (2017). Industrial Internet of Things. Cham, Switzerland: Springer Verlag. doi: 10.1007/978-3-319-42559-7.

Kawaguchi, N. (2019). Application of Blockchain to Supply Chain: Flexible Blockchain. Procedia Computer Science. CENTERIS - International Conference on ENTERprise Information Systems; ProjMAN - International Conference on Project MANagement; HCist - International Conference on Health and Social Care Information Systems and Technologies, 164, 143-148. doi: 10.1016/j.procs.2019.12.166.

Maddison, A. (2006). The World Economy. Paris, France, Development Centre Studies, OECD Publishing. doi: 10.1787/9789264022621-en.

Nayak, A., \& Dutta, K. (2017). Impacts of machine learning and artificial intelligence on mankind. International Conference on Intelligent Computing and Control (I2C2). Coimbatore, India. doi: 10.1109/I2C2.2017.8321908.

Russell, S., \& Norvig, P. (2009). Artificial Intelligence. $3^{\text {rd }}$ edition. Premtice Hall.

Smith, A. (1776). An Inquiry into the Nature and Causes of the Wealth of Nations. London, William Strahan.

Varga, P., Kathareios, G., Mate, A., Clauberg, R., Anghel, A., Orosz, P., ... Gusat, M. (2017). Real-Time Security Services for SDN-based Datacenters. $13^{\text {th }}$ International Conference on Network and Service Management (CNSM) (pp. 924-929). Tokyo, Japan. doi: 10.23919/ CNSM.2017.8256030.

Watanabe, H., Fujimura, S., Nakadaira, A., Miyazaki, Y., Akutsu, A., \& Kishigama, J. (2016). Blockchain Contract: Securing a Blockchain Applied to Smart Contracts. 2016 IEEE International Conference on Consumer Electronics (ICCE) (pp. 467-468). Las Vegas, Nevada, USA. doi: 10.1109/ICCE.2016.7430693.

Wu, R., Vanan, G.T., \& Phillips, M. (2016). The internet of things (IoT) and transformation of the smart factory. International Electronics Symposium (IES).

Article history:

Received: 10 April 2020

Revised: 15 May 2020

Accepted: 25 May 2020

\section{For citation:}

Clauberg, R. (2020). Challenges of digitalization and artificial intelligence for modern economies, societies and management. RUDN Journal of Economics, 28(3), 556-567. http:// dx.doi.org/10.22363/2313-2329-2020-28-3-556-567

\section{Bio note:}

Rolf Clauberg, Dr.rer.nat. (PhD in Natural Sciences), Associate Professor of the Management Department of the Faculty of Economics of the Peoples' Friendship University of Russia (RUDN University). E-mail: klauberg-r@rudn.ru 


\title{
Проблемы цифровизации и искусственного интеллекта в сферах современной экономики, общества и управления
}

\author{
Р. Клауберг \\ Российский университет дружбы народов \\ Российская Федераиия, 117198, Москва, ул. Миклухо-Маклая, 6
}

\begin{abstract}
Аннотация. Исследование направлено на выявление проблем цифровизации и искусственного интеллекта в сферах современной экономики, общества и делового администрирования. Внедрение таких схем цифровизации, как Индустрия 4.0, в настоящее время является официальной политикой многих развитых стран. Цель - оптимизация производственных процессов и цепочек поставок. Искусственный интеллект также влияет на многие области. Ожидается, что обе технологии существенно изменят условия труда для многих людей. Важно определить характер и последствия этих изменений, а также возможные средства минимизации негативных последствий. Для этого в данном исследовании используются результаты предыдущих работ, изучающих исчезновение производственных рабочих мест в США и его влияние на различные группы общества, вместе с технической информацией о новых технологиях для прогнозирования ожидаемых изменений, вызванных цифровизацией и искусственным интеллектом. Становится очевидным, что обе технологии уничтожают большое количество рабочих мест и способствуют исчезновению целых классов профессий, одновременно создавая новые рабочие места, сильно отличающиеся от уничтоженных. Многостороннее постоянное образование и переклассификация работников будут необходимы для минимизации негативных последствий и улучшения потенциала смены работы в совершенно новых областях. Кроме того, техническая информация о цифровизации в киберфизических системах указывает на опасности, которые потребуют решения на международном уровне.
\end{abstract}

Ключевые слова: искусственный интеллект, кибербезопасность, кибертерроризм, цифровизация, валовой внутренний продукт, Индустрия 4.0

\section{История статьи:}

Дата поступления в редакцию: 10 апреля 2020 г.

Дата проверки: 15 мая 2020 г.

Дата принятия к печати: 25 мая 2020 г.

\section{Для цитирования:}

Clauberg $R$. Challenges of digitalization and artificial intelligence for modern economies, societies and management // Вестник Российского университета дружбы народов. Серия: Экономика. 2020. Т. 28. № 3. С. 556-567. http://dx.doi.org/10.22363/2313-2329-202028-3-556-567

\section{Сведения об авторе:}

Клауберг Рольф, кандидат экономических наук, доцент кафедры менеджмента экономического факультета Российского университета дружбы народов. E-mail: klauberg-r@ rudn.ru 